\title{
Analytical aspects of effective stock-raising when applying high- protein fodder
}

\author{
Vera Konkina ${ }^{1, *}$, Olga Lukyanova ${ }^{2}$,Elena Pravdina $^{3}$ and Elena Kuvshinova ${ }^{4}$ \\ ${ }^{1}$ Ryazan State Agrotechnological University Named after P.A. Kostychev, Department of Economics and Management, 390044 Ryazan, \\ Russia \\ ${ }^{2}$ Ryazan State Agrotechnological University Named after P.A. Kostychev, Department of Agronomy and Agricultural Technologies, \\ 390044 Ryazan, Russia \\ ${ }^{3}$ Ryazan State Agrotechnological University Named after P.A. Kostychev, Department of Zootechnology and Biology, 390044 Ryazan, \\ Russia \\ ${ }^{4}$ SHC Vishnevsky LLC, Orenburg, Russia
}

\begin{abstract}
The work provides a comprehensive analysis of efficient organization in the stock-raising industry when fed with high protein fodder. For that end, a dynamic analysis of volume and geographical indicators of soybean production, as well as ways to increase productivity, was initially conducted. The authors believe that biologically active preparations should be used for pre-treatment of seeds and foliar top dressing of plants. This will increase the yield by 2-3 dt/ha and the protein content by 3-4\%. The next step in the analytical procedures was conducting an experiment connected with introduction of soybean meal into the diet of young pigs. This will improve the physiological state of pigs and intensify their live weight gain.
\end{abstract}

\section{Introduction}

In modern economic realities, efficient stock-raising is possible only with the use of resource-saving technologies and technical means aimed at providing animals with high-quality fodders without increasing operating costs.

The role of protein was first studied by the French scientist F. Majandi (1816). In Russia, research on the needs of animals in mineral substances was conducted (1872) by A. Rubets. N. I. Lunin established (1880) the presence of substances in products that were later (1912) called vitamins. The qualitative transformation of substances in the animal body was studied By N.P. Chirvinsky, who proved (1881) the possibility of fat formation in the animal body from carbohydrates. E.A. Bogdanov (1909) showed the possibility of fat formation from feed protein. Research by V.V. Pashutin and his students (late 19th - early 20th centuries) was the theoretical basis for the study of metabolism in animals. The method of accounting for the balance of substances and energy of animals was developed, and the method of scientific and economic experiments with animals was improved.

Formation of a reliable, well-balanced fodder base and possible reduction of the fodder nutritional value during the gathering is to the great extend determined by the proper organization of fodder production and conservation. The creation of high-value fodder base for breeding development depends both on a proper selection of crops and their biological peculiarities. Thus, in this research we studied the biological peculiarities of growth and development, capacity formation of different crops of pure and mixed sowing. As the result of these investigations, we have obtained some data, which allow us to estimate the capacity of feed crops of pure and mixed sowing in soil and climatic conditions of the Central Federal District for use in innovative techniques of production of fodder protein. [1]

\section{Materials and methods}

An analysis of the activities of agricultural enterprises shows that an increase in the productivity of animals and poultry follows an increase in the proportion of proteinrich fodders in the diet. At the same time, the deficiency of protein in the diet of farm animals leads to a reduced profitability of livestock products due to insufficient productivity of animals and poultry.

According to analytical data, soybean production and demand for it in Russia is growing every year, following the needs of stock-raising. This crop, due to the rich complex of proteins, fats, carbohydrates, mineral salts and vitamins contained in soybean grain, allows replenishing the animal feed base with high-quality products such as soybean oilcakes, protein meal, oil and protein isolate. Soybeans and fodder products made from them are characterized by a high protein content and, as a result, high content of amino acids, a saturated energy base and good digestibility. Soy exceeds the grain feed group (barley, corn, etc.) in the amount of digestible protein by

Corresponding author: konkina_v@mail.ru 
3.5-4.0 times, and due to the energy of protein and oil, 1 ton of soy replaces 10 tons of fodder wheat. [2]

According to the data of Maria Domoroschenkova, head of the Food Vegetable Protein and Biotechnology department of the All-Russian Research Institute of Fats, sunflower seed dominates the structure of oilseed processing (Figure 1), and its oilcakes and meal comprise the largest share in the total volume of this production. However, if the total production of oilcakes and meal in Russia over the past decade has increased almost by a factor of 3, amounting to about 6.45 million tons, while the volume of soybean products over this time increased by more than 18 times to 2.5 million tons.

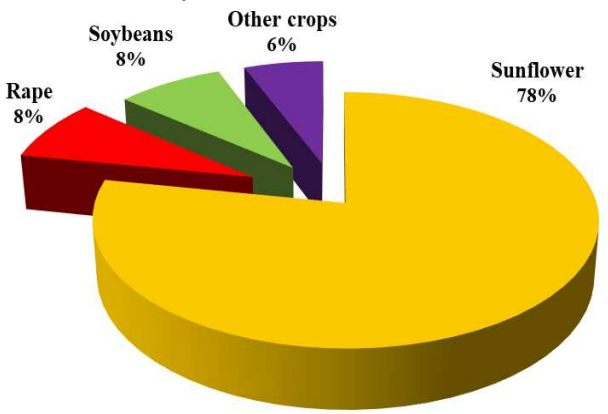

Fig. 1. Structure of oilseed processing in the Russian Federation, \%

In 2019, sown areas of soybeans in farms of all categories occupied 3,039.4 thousand ha, increasing by 90.2 thousand ha or $3.1 \%$ compared to 2018. Analysis of statistical data for 2001-2019 showed that the area under this crop increased by 2,622.8 thousand ha or $629.6 \%$ (Figure 2).

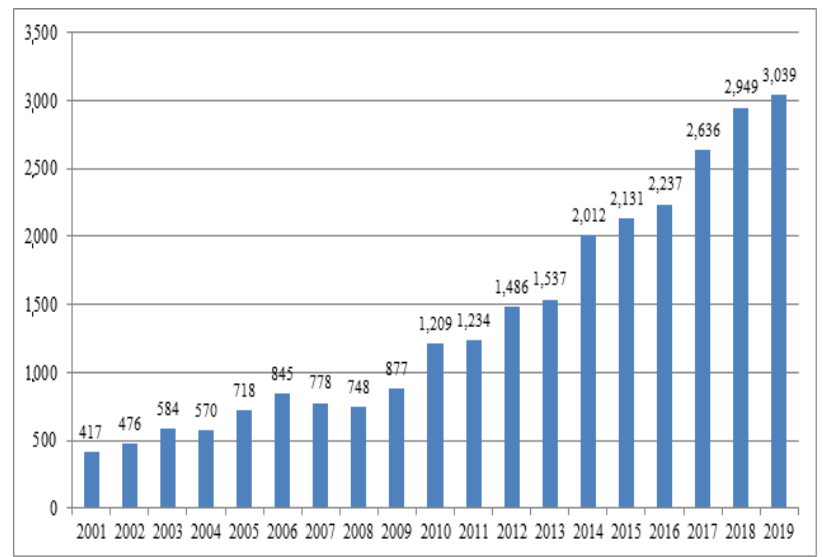

Fig. 2. Dynamics of changes in sown areas of soybeans in the Russian Federation in 2001-2019, thousand ha

Amur Region traditionally remains the main region in terms of sown area, which accounts for almost a third of all soybean crops in the country. Primorsky Krai, Kursk and Belgorod Regions, and Krasnodar Krai are also significant soy-producing regions (Figure 3).

Soybean has a high degree of adaptability to various soil and climatic conditions, which, when using early ripening varieties, allows it to be cultivated in large areas with temperate climate. This leads to an increase in sown areas of soybean in the Central region, which allows stabilizing its production in Russia due to the cultivation of crops in various climatic zones of the country. The expansion of the geography of soybean cultivation helps to reduce the dependence of production on agrometeorological conditions during the growing season and harvesting, which remain one of the main factors holding back obtaining high and stable crop yields. [5]

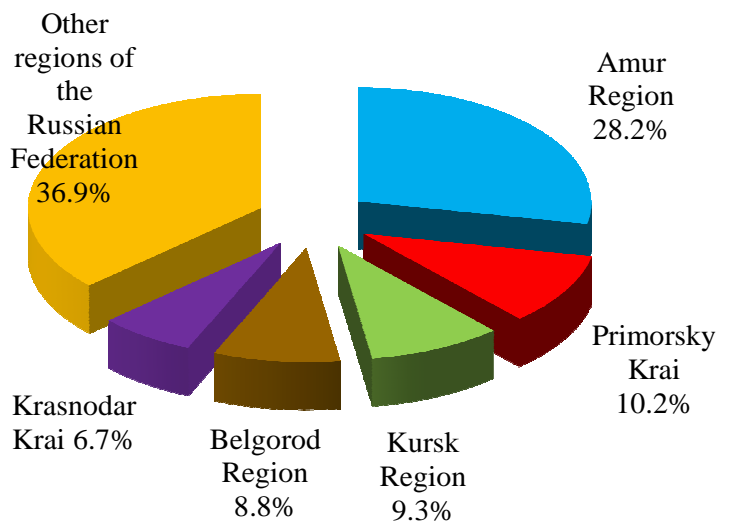

Fig. 3. Regions of the Russian Federation with the largest soybean sowing area, \%

Due to adverse weather conditions in the Far Eastern Federal District, which is a key region for soybean production, the gross yield in 2019 compared to 2018 decreased by 325.2 thousand tons or $19.7 \%$. However, according to the Federal State Statistics Service, Russia received its maximum yield of 4.36 million tons in 2019 due to the expansion of soybean acreage in the Center of Russia, the South and Siberia. The main volume of soybean was threshed in the Central Federal District and it was 2.12 million tons or $49.0 \%$ of the total Russian gross yield.

The geographical factor has also a significant impact on the specifics of the domestic Russian soybean market. In the Far East, soybean exports are growing due to the remoteness from processing enterprises and animal husbandry centers, and the central regions of Russia import it, since soybean processing capacities in this region exceed the volume of raw material production.

\section{Results}

It is possible to increase soybean production not only through extensive measures, but also through intensification of production. The increase of productivity is one of the ways. In 2019, the average soybean yield in the Russian Federation amounted to $15.7 \mathrm{~kg} / \mathrm{ha}$, varying from $11-13 \mathrm{~kg} / \mathrm{ha}$ in the Far East to $15-17 \mathrm{~kg} / \mathrm{ha}$ in the Center of Russia. Low yield is caused by the lack of zoned seeds, disturbance of agricultural technology and climatic conditions. [9]

At the same time, the growth in soybean production should not affect the quality of its processing. According to experts of domestic processing enterprises, the protein content in soybeans grown in Russia is $29-34 \%$, while this indicator in beans produced, for example, in Paraguay, reaches $36 \%$.

Studies conducted on gray forest loamy soil in Ryazan region, at the experimental agro-technological station of the Ryazan State Agrotechnological 
University, showed that soybean yields on control varied from $12.2 \mathrm{dt} / \mathrm{ha}$ (2013) to $21.2 \mathrm{dt} / \mathrm{ha}$ (2017). The use of plant growth regulators in soybean cultivation made it possible to increase the yield by an average of 2-3 dt/ha and increase the protein content by 3-4\%.

So, in 2015 , the soybean yield was $26.1 \mathrm{dt} / \mathrm{ha}$, which was higher than the control indicator by $6.8 \mathrm{dt} /$ ha with HCP05 $=2.4 \mathrm{dt} / \mathrm{ha}$. The more productive option used seeds pre-treatment with organomineral fertilizer RaikatSoMo and foliar top dressing of plants at the stage of 2-3 leaves as well as in the budding phase $(3.01 / \mathrm{t}+$ $300 \mathrm{ml} / \mathrm{ha})$. The protein content in this option was $34.1 \%$ and it was $27.6 \%$ in the control.

Thus, along with the recommended varieties, the use of biologically active compounds with a protective and stimulating effect that increase the adaptation and antistress activity of soybean in various agro climatic zones is an important reserve for increasing the yield and quality of soybean seeds.

Summarizing the state of the oilseed industry, it should be noted that at present soybean remains one of the most profitable crops (the average profitability in the Russian Federation is $59.4 \%$ ), that has led to an average growth rate of sown area at $8.7 \%$ for the past 5 years. The presence of stable and growing demand, as well as support by the Ministry of Agriculture of the Russian Federation for domestic soybean producers in the amount of 7.9 billion rubles, will contribute to an increase in its production, primarily in the Center and in the south of Russia, where intensive development of stock-raising continues. [3]

As previously noted, soybean is an excellent forage crop that contains a rich complex of proteins, fats, carbohydrates, mineral salts and vitamins. An urgent task of modern stock-raising is the formation of a system of complete feeding of farm animals, including their provision with protein. In recent years, a lot of research has been carried out on the use of soybeans in the feeding of farm animals, both in our country and abroad. Therefore, there is no question about the feasibility of including soybeans into the diet of farm animals.

The problem of high-grade protein nutrition is the most important in feeding pigs, since uninterrupted, varied and biologically high-grade protein feeding provides satisfactory reproduction of the herd, high early maturity, vitality and productivity of farm animals.

There are several ways to solve this problem:

- to increase protein production by expanding the area under protein crops and the search for new sources of nitrogenous substances;

- to have rational use of protein resources when feeding pigs.

To create an effective and balanced nutrition system for farm animals, it should be borne in mind that the use of protein is influenced by a complex of factors, including:

- ratio of nutrients in the diet;

- quality and usefulness of protein feeding;

- use of biologically active substances (vitamins, antibiotics, trace elements);

- overall nutritional status;
- type of feeding.

Biologically defective and inadequate protein feeding of pigs causes growth inhibition and decreased productivity. There is a decline in the weight gain of young pigs and feed consumption increases by $25-30 \%$, which leads to an increase in the cost of production.

At the same time, the growth rate of pigs at different age periods varies significantly, so the need for protein also changes. So, the daily requirement for digestible protein for 2-month-old piglets is 165-190 grams, for 4-month-old pigs it is 180-225 grams, for 7-month-old pigs it is 260-330 grams, for 10-month-old pigs it is 300-350 grams and for 12 -month-old pigs it is 340-405 grams. However, if calculated per $1 \mathrm{~kg}$, the demand actually gradually decreases from 9-10 grams at 2 months of age to $4-6$ grams at 4 months, 3-4 grams at 7 months and 2 grams at 12 months of age. [6]

The experiments carried out on domestic pig farms showed that the level of protein feeding in the diets of growing pigs has a significant effect on the growth rate, its composition and calorie content. If the feed is selected so that the amino acids of the diet fully meet the needs of the animals (without shortages or surpluses), then, under other normal conditions, a high effect is achieved in the growth, productivity and use of protein. Otherwise, growth retardation and meat quality deterioration occur. There is a relationship between the quantity and quality of protein in pig diets, as well as the effect of balancing the diet in limiting essential amino acids on animal productivity and the quality of products.

To assess the balance of the feed ration, as a result of the use of soybean meal, and its effect on the growth of young pigs an economic experiment took place in SHC Vishnevsky LLC. For research, 3 groups of young Landras pigs, 35 animals each, were formed by the method of pair analogues. The experimental design is presented in Table 1.

Table 1. Design of the experiment.

\begin{tabular}{|c|c|c|}
\hline Group & Number of pigs & Feeding conditions \\
\hline Control & 35 & BD (basic diet) \\
\hline Experimental 1 & 35 & $\begin{array}{l}\text { BD }+11.5 \% \\
\text { soybean meal }\end{array}$ \\
\hline Experimental 2 & 35 & $\begin{array}{l}\text { BD }+16.5 \% \\
\text { soybean meal }\end{array}$ \\
\hline
\end{tabular}

All animals in the enterprise were in the same conditions. Feeding of young animals was carried out according to the scheme adopted at the enterprise, in accordance with the requirements of the norms depending on their age and sex group and growth. The main diet included grain mix (barley, wheat, peas) of inhouse production, enriched with premix. [7, 8]

Animals of the experimental groups received the main diet, but with a different percentage of soybean meal. The composition and nutritional value of the diets are presented in Table 2. According to the main nutritional indicators, the diets of young pigs in experimental groups corresponded to the needs of animals of these age groups.

Assessment of pig growth was carried out according to the following indicators: absolute and average daily 
gains, early maturity and feed conversion. All material received was processed using modern information technology.

Table 2. Composition and nutritional value of mixed fodders with different content of soybean meal.

\begin{tabular}{|c|c|c|}
\hline Indicator & SK-4 & SK-5 \\
\hline \multicolumn{3}{|c|}{ ACTUAL CONTENT, $\%$} \\
\hline Barley & 25.0 & 30.00 \\
\hline Wheat & 44.5 & 41.20 \\
\hline Soybean Meal & 16.5 & 11.50 \\
\hline Peas & 2.5 & 2.50 \\
\hline Sunflower Oil & 3.3 & 2.50 \\
\hline Fodder Lime & 0.8 & 0.80 \\
\hline Monocalcium Phosphate & 0.6 & 0.50 \\
\hline Salt & 0.5 & 0.50 \\
\hline Adsorbent & 0.3 & 0.20 \\
\hline \multicolumn{3}{|c|}{ NUTRIENT INDEXES, \% } \\
\hline Dry Matter & 88.50 & 88.50 \\
\hline Crude Protein & 17.6 & 18.121 \\
\hline Crude Fat & 4.56 & 4.973 \\
\hline Crude Fibre & 3.20 & 2.862 \\
\hline Lysine & 1.29 & 1.252 \\
\hline Methionine & 0.412 & 0.431 \\
\hline Methionine + Cystine & 0.692 & 0.735 \\
\hline Threonine & 0.822 & 0.849 \\
\hline Tryptophan & 0.260 & 0.264 \\
\hline $\mathrm{Ca}$ & 0.644 & 0.675 \\
\hline $\mathrm{P}$ & 0.483 & 0.477 \\
\hline $\mathrm{Na}$ & 0.236 & 0.218 \\
\hline
\end{tabular}

\section{Discussion}

During the experiment, it was found that balancing the diet by protein by including soybean meal into the diets had a positive effect on the general physiological state of pigs and their growth rate. Experimental data on changes in live weight and live weight gain in experimental animals are shown in Table 3 .

Table 3. Change in live weight of pigs during the economic experiment

\begin{tabular}{|c|c|c|c|}
\hline \multirow{2}{*}{ Indicator } & \multicolumn{3}{|c|}{ Group } \\
\cline { 2 - 4 } & Control & Experimental 1 & Experimental 2 \\
\hline $\begin{array}{c}\text { At the } \\
\text { beginning of the } \\
\text { experiment, kg }\end{array}$ & $7.8 \pm 0.24$ & $7.8 \pm 0.24$ & $7.8 \pm 0.24$ \\
\hline $\begin{array}{c}\text { At the end of } \\
\text { the experiment, } \\
\mathrm{kg}\end{array}$ & $110.3 \pm 0.37$ & $111.3 \pm 0.37$ & $113.4 \pm 0.37^{*}$ \\
\hline Absolute, kg & $102.5 \pm 1.16$ & $103.4 \pm 1.18$ & $105.8 \pm 1.28^{*}$ \\
\hline $\begin{array}{c}\text { The average } \\
\text { daily, g }\end{array}$ & $748.5 \pm 10.4$ & $755.2 \pm 10.5$ & $787.8 \pm 10.8^{*}$ \\
\hline $\begin{array}{c}\text { Early maturity, } \\
\text { days }\end{array}$ & $168 \pm 2.2$ & $166 \pm 2.3$ & $163 \pm 2.3^{*}$ \\
\hline$* \mathrm{P} \leq 0.005$ & & \\
\hline
\end{tabular}

$$
* \mathrm{P} \leq 0.005
$$

When setting up an experiment, the live weight of piglets of different groups at the age of 28 days was almost the same $-7.8 \pm 0.24 \mathrm{~kg}$ (the difference was not significant). At the end of the experimental period, the live weight of animals in the control group was $110.3 \pm 0.37 \mathrm{~kg}$, the first experimental group had $111.3 \pm$ $0.37 \mathrm{~kg}$ and the second experimental group had $113.4 \pm$ $0.37 \mathrm{~kg}$. [4]

Thus, at the end of the experiment, animals of the second experimental group receiving $16.5 \%$ of soybean meal in the diet exceeded the weight of pigs in the first experimental and control groups by $2.1 \mathrm{~kg}$ and $3.1 \mathrm{~kg}$, respectively. [11]

The absolute gain in live weight in the second experimental group was higher than in the first one, and averaged $103.4 \pm 1.18 \mathrm{~kg}$. The average daily gains in live weight of young animals in the groups for the period of the experiment, respectively, amounted to $755.2 \pm 10.5 \mathrm{~g}$ (the first experimental group) and 787.8 $\pm 10.8 \mathrm{~g}$ (the second experimental group). Whereas in the control group this indicator was $748.5 \pm 10.4 \mathrm{~g}$. The age of reaching a live weight of $100 \mathrm{~kg}$ in the first experimental group was $166 \pm 2.3$ days, while in the second group this indicator was $163 \pm 2.3$ days, which is 5 days less compared to the control group. Consequently, the use of soybean meal in pig diets has a positive effect on the growth of young animals. [10]

\section{Conclusion}

The intensive growth in live weight and earlier maturity of young pigs ensured the agricultural enterprise increased pork production efficiency (Table 4).

Table 4. The economic rationale for the effectiveness of feeding young animals with soybean meal

\begin{tabular}{|c|c|c|c|}
\hline \multirow{2}{*}{ Indicator } & \multicolumn{3}{|c|}{ Group } \\
\cline { 2 - 4 } & Control & Experimental 1 & Experimental 2 \\
\hline $\begin{array}{c}\text { Early maturity, } \\
\text { days }\end{array}$ & 168 & 166 & 163 \\
\hline $\begin{array}{c}\text { Feed conversion, } \\
\text { kg/kg }\end{array}$ & 2.9 & 2.8 & 2.6 \\
\hline Weight gain, kg & 102.5 & 103.4 & 105.8 \\
\hline $\begin{array}{c}\text { Selling price of 1 } \\
\text { kg, rub. }\end{array}$ & 150 & 150 & 150 \\
\hline $\begin{array}{c}\text { Additional } \\
\text { products, kg }\end{array}$ & - & 0.9 & 3.3 \\
\hline $\begin{array}{c}\text { The cost of } \\
\text { additional } \\
\text { products, rub. }\end{array}$ & - & 135 & 495 \\
\hline
\end{tabular}

The data in Table 4 clearly show that early maturity was higher in young animals of the second experimental group and amounted to an average of 163 days, which was 3 days less than in young animals of the first group and 5 days less than in young animals of the control group.

Feed conversion per $1 \mathrm{~kg}$ of growth was also lower in young animals of the second experimental group and amounted to $2.6 \mathrm{~kg}$, which was lower than in young 
animals of the first and control groups by 0.2 and $0.3 \mathrm{~kg}$, respectively.

Thus, feeding soybean meal to young pigs when rearing and fattening makes it possible to receive additional income per head in the amount of 135 and 495 rubles, respectively, depending on the percentage of soybean meal.

\section{References}

1. A.S. Zavgorodnyaya, I.G. Shashkova, V.S. Konkina et al., Adaptive Management of the Agricultural Enterprise in the Conditions of Environmental Uncertainty, J. of Advan. Res. in Dynamical and Control Syst., 7 (Special Issue), 2022-2031 (2018)

2. D.V. Vinogradov, V.S. Konkina, Y.V. Kostin et al., Developing the regional system of oil crops production management, Res. J. of Pharmace., Biolog. and Chem. Sci. (RJPBCS), 9(5), 1276-1284 (2018)

3. E.P. Polikarpova, I. E. Mizikovskiy, Preparing accounting information on costs for manufactured crop production, Custos e Agronegocio, 14(4), 149166 (2018)

4. S.A. Nefedova, A.A. Korovushkin, G.M. Tunikov et al., Immunoferment, Cytomorphological, Cytochemical Parameters of Fish as Ecological Indicators of Resistance to Helminthes, Passed by Fish-Eating Birds, Int. J. of Engineer. and Technol., 7(4.36), 217-221 (2018)

5. R.N. Ushakov, A.V. Ruchkina, V.I. Levin et al., Sustainability of Agro-Gray Soil to Pollution and
Acidification, and its Biodiagnostics, Int. J. of Engineer. and Technol., 7(4.36), 929-934 (2018)

6. G.M. Tunikov, N.I. Morozova, F.A. Musaev et al., Economic and Biological Features of the Holstein Cows Selected in Hungary when Year-Round Stable System, Int. J. of Engineer. and Technol., 7(4.36), 935-940 (2018)

7. V.K. Chebotar, A.N. Zaplatkin, A.V. Shcherbakov et al., Microbial preparations on the basis of endophytic and rhizobacteria to increase the productivity in vegetable crop and spring barley (Hordeum vulgare L.), and the mineral fertilizer use efficiency, Agricultural Biology, 51(3), 335-342 (2016)

8. K.P. Andreev, Zh.V. Danilenko, M.Yu. Kostenko et al., Determining the Inequality of Solid Mineral Fertilizers Application, J. of Advan. Res. in Dynam. and Control Syst., 10 (Special Issue), 2112-2122 (2018)

9. G.I. Churilov, D.G. Churilov, S.G. Churilov et al., Plants Nutrition and Growth Stimulation with the Help of Nanotechnologies, Int. J. of Engineer. and Technol., 7(4.36), 231-236 (2018)

10. T.N. Belova, Processes of import substitution in the agri-food sector, Econ. of the reg., 15(1), 285-297 (2019)

11. V. Konkina, A. Shemyakin, I. Babkin, Information and software of managing the industry cluster of the region, Proc. of the 33rd Int. Business Information Management Association Conf., IBIMA 2019: Education Excellence and Innovation Management through Vision, pp. 8632-8637 (2020) 